\title{
Advances in cystoscopic surveillance of superficial bladder cancer: detection of the invisible tumor
}

\author{
Nathan Edward Hale* and Samuel Deem \\ *Correspondence: nhaleurology@gmail.com \\ Charleston Area Medical Center, USA.
}

\begin{abstract}
Objectives: To review recent advances in imaging modalities available for diagnosis and surveillance of superficial bladder cancer. Methods: Detailed PubMed searches were performed using the terms "fluorescence cystoscopy," "narrow-band imaging," and "optical coherence tomography" with "bladder cancer" and "urothelial carcinoma." Relevant literature was selected for analysis. We explored the clinical evidence to support the use of these technologies for the detection and surveillance of bladder cancer.

Results: Fluorescence cystoscopy, narrow-band imaging, and optical coherence tomography are designed to improve the visualization of bladder cancer. These technological advancements have demonstrated an improvement in the detection of bladder cancer, including carcinoma in situ. Fluorescence cystoscopy has also been shown to decrease residual tumor rates and improve recurrence free survival. Both fluorescence cystoscopy and narrow-band imaging have a relatively high false positive rate. Optical coherence tomography can estimate bladder tumor stage without an invasive biopsy, however data is lacking in diagnostic accuracy.

Conclusions: Evidence for the utility of fluorescence cystoscopy, narrow-band imaging, and optical coherence tomography has begun to compile. Fluorescence cystoscopy has the most evidence supporting its clinical applications. Low specificity currently limits these novel technologies from widespread use. More prospective studies are needed particularly of narrow band imaging, and optical coherence tomography. In addition, further research is necessary to determine the long-term impact of these technologies on recurrence, progression, and survival of bladder cancer.
\end{abstract}

Keywords: Fluorescence cystoscopy, bladder cancer, narrow-band imaging, urothelial carcinoma, optical coherence tomography, cystoscopy

\section{Introduction}

According to the National Cancer Institute, approximately 69,250 new cases of bladder cancer will be diagnosed in the United States in 2011. Bladder cancer is currently ranked the sixth most common cancer in the developed world [1]. The National Cancer Institute's Surveillance Epidemiology and End Results (SEER) Registry reports that the incidence of bladder cancers diagnosed has increased by approximately $40 \%$ over three decades [2]. This increase is likely multi-factorial and not well understood. The diagnostic tools available for use have remained relatively constant since the 1930's. Malignancy is suspected based on the visible changes seen endoscopically with white light cystoscopy (WLC) and/or biopsy of suspicious lesions.

Approximately $75 \%$ of cases of bladder cancer will present as non-muscle invasive disease and therefore, have good prognosis in terms of cancer-specific survival [3]. Visualization and biopsy allow the clinician to assess the location and extent of the tumor to developing a treatment plan and appropriate follow-up. Recurrence rates reported as high as $75 \%$ lead to the necessity of close lifelong follow-up with cystoscopy and cytology as well as repeated treatment [3]. The requirement of follow-up and repeated treatment has made bladder cancer one of the most expensive cancers in today's medical practice [4]. WLC and biopsy remain the standard of care; however, recent technological advancements may be shifting the standard of care in a new direction.

WLC has a sensitivity and specificity ranging from $62-84 \%$ and $43-98 \%$ respectively [5]. Many urinary markers have been developed to improve detection; however no marker or combination of markers can outperform cystoscopy. Despite being the current standard, WLC has limitations particularly with detecting small papillary bladder tumors and carcinoma in situ. Up to $70 \%$ of patients will have residual bladder cancer after transurethral resection of bladder tumor (TURBT) $[6,7]$. These recurrences may be caused by inability to identify tumor and/or regrowth of residual tumor after incomplete resection. In either of these scenarios, recurrence occurs because of the clinician inability to adequately visualize the disease tissue. Advancement in endoscopic visualization of bladder tumors will be necessary to improve recurrence rates and overall cancer survival. The purpose of this paper is to review the recent advances in imaging modalities available for cystoscopic diagnosis and surveillance of superficial bladder cancer: fluorescence cystoscopy, narrow-band imaging, and optical coherence. 
Hale et al. Medical Instrumentation 2013,

\section{Methods}

Detailed PubMed searches were performed using the terms "fluorescence cystoscopy," "narrow-band imaging," and "optical coherence tomography" with "bladder cancer" and "urothelial carcinoma." Clinically relevant articles published in the English language were selected for analysis including in vivo and ex vivo use of these technologies in the urinary tract. We explored the clinical evidence to support the use of these technologies for the detection and surveillance of bladder cancer. Clinical results were summarized in the body of this text.

\section{Fluorescence cystoscopy}

Fluorescent cystoscopy (FC) is a new diagnostic procedure utilizing photoactive porphyrins to enhance the detection of bladder cancer. FC is accomplished by intravesical administration of 5 -aminolevulenic acid (5-ALA) or hexaminolevulinate $(H A L)$. The metabolism of aminolevulinic acid $(A L A)$ is the first step in the biochemical pathway resulting in heme synthesis. ALA is not a photosensitizer, but rather a metabolic precursor of protoporphrin IX (PpIX), which is a photosensitizer. PplX selectively accumulates in rapidly proliferating cells and are detected at light wavelength of 360-450 to distinguish between cancerous and normal tissue. Over the last decade improvements such as intravesical rather than systemic administration, use of newer photoactive porphyrins, shorter installation time, better contrast and less photobleeching have made this technique significantly better at detecting bladder cancer and much more practical $[8,9]$. HAL is the photoactive porphyrin that has shown to be most effective and is the primarily one in use today [9]. HAL lipophilic nature has made this technique practical by shortening the infusion time.

FC is typically performed by infusing $50 \mathrm{~mL} 8 \mathrm{mM}$ hexaminolevulinate hydrochloride solution into the bladder for 1 to 3 hours. The bladder is drained 30 minutes prior to completing any cystoscopic examination. WLC is performed followed by a special cystoscope utilizing blue light. The photoactive porphyrins accumulated in the neoplastic tissue emit red fluorescence under blue-wavelength light improving the detection of small papillary lesions and CIS. Both rigid and flexible cystoscopy can be performed [10]. The difference between rigid and flexible cystoscopy is the stiffness of the instrument used. Rigid cystoscopy is routinely performed in the operating room under anesthetic to reduce patient discomfort. Flexible cystoscopy decreases the discomfort and is offered in the office setting. However, fluorescence rigid cystoscopy resulted in a higher tumor detection rate than using flexible cystoscopes (85-94\% vs. 70-89\% respectively) [11,12]. Currently the FDA has only approved rigid cystoscopy outside of experimental protocols. Flexible blue light cystoscopy will allow this technology to become an office procedure.

Multiple studies have demonstrated that FC improves the detection of superficial bladder cancer when compared to WLC alone [10,13-18]. Kausch et al., recently performed a meta-analysis of 17 prospective randomized trials [19]. This meta-analysis revealed a $20 \%$ improved detection rate of superficial bladder cancer using FC. Approximately 39\% more tumors were identified if the analysis was limited to carcinoma in situ. Lesion based specificity was found to be $79 \%$ for FC and $93 \%$ for WLC. False positive rate were found to be higher in the FC groups. Ray et al., reported that especial high false positive biopsy rates for FC-guided biopsies in the setting of post Bacillus Calmette-Guerin treatment [41]. Residual tumor was seen in 15\% after FC and 35\% after WLC alone. Recurrence-free survival at 12 months and 24 months improved from $15.8 \%$ to $24 \%$ and $12 \%$ to $15 \%$ when using FC compared to WLC alone.

In addition to improved detection, FC has been shown to reduce the incidence of recurrence by using fluorescence at the time of the TURBT. Several short term prospective studies revealed a significant reduction in the rate of tumor recurrence $[19,50,51]$. However, Schumacher et al., found similar recurrence rates [47]. Daniltchenko et al., reported a five year recurrence rates at $75 \%$ and $59 \%$ in the WLC and FC groups, respectively [48]. Densinger et al., similarly found a statistically significant difference in recurrence rates favoring fluorescent TUR after eight years of follow up when compared to standard TURBT under white light [49]. In summary, FC is photodynamic cystoscopic procedure that improves detection, decreases residual tumor rates, and increases recurrence free survival.

\section{Narrow-band imaging}

Narrow-band imaging (NBI) in an endoscopic optical image enhancement technique improves visualization of the microvascular structures without using an intravesical infusion. The depth of light penetration into the bladder wall increases with increasing wavelength. NBI works by filtering white light into two narrow bandwidths within the light spectrum: blue (415 nm) and green (540 nm). These wavelengths only penetrate the superficial bladder wall and are specifically absorbed by hemoglobin $[\mathbf{2 0}, \mathbf{2 1}]$. Consequently, the vascular structures appear brown/green compared to the surrounding mucous thus improving visualization of vascularized lesions. Bladder tumors tend to be more vascularized than normal bladder mucosa. Combined WLC and NBI systems are now becoming commercially available where the NBI wavelength is activated by the push of a button.

The use of NBI for the detection of bladder cancer was first described in 2007 [26]. Several studies have shown improved bladder cancer detection with NBI over WLC [22-25]. Based upon these studies, NBI identified $22-56 \%$ additional tumors. The reported false positive rates ranged from 32 to $36 \%$ [23-25]. Cauberg et al., reports improved detection of both high and low grade tumors when compared to white light cystoscopy [22]. Tamsugami et al., reported a sensitivity and specificity of $92.7 \%$ and $70.9 \%$, respectively [27]. Herr et al., showed that the use of NBI was associated with fewer recurrences and longer recurrence-free intervals [28]. However, to our knowledge there are no published randomized control trials to support 
Hale et al. Medical Instrumentation 2013,

the use of this technology. The Clinical Research Office of the Endourological Society recently launched an international randomized trial to evaluate NBI [29]. In summary, NBI appears to result in better bladder cancer detection without the use of an intravesical infusion. Clearly further research is needed before routine use of NBI for bladder cancer diagnosis and treatment.

\section{Optical coherence tomography}

Optical coherence tomography (OCT) is a noninvasive imaging technique that uses near-infrared light waves for the crosssectional images containing subsurface tissue information. This technology is similar to ultrasound imaging, except that it is based on depth resolved detection of backscattered light instead of reflected sound waves. OCT produces high resolution images approaching the resolution of a microscopy (up to $2 \mu \mathrm{m}$ ) and a maximum imaging depth of 2-3mm [30]. OCT discriminates normal bladder mucosa from bladder cancer based upon qualitative analysis of the images: normal mucosa is uniform and the bladder walls are clearly delineated based upon their different backscattering capacities versus bladder cancer increased the backscattering producing heterogeneity. Extensive research has been performed using OCT in the field of ophthalmology for visualizing the retina, and has recently gained attention in urology. OCT probe can be inserted through the working channel of a cystoscope and provide real-time identification of bladder tumors.

Several studies have been conducted on the ability of OCT to detect bladder cancer. These studies have demonstrated that the different bladder wall layers including the lamina propria and the muscularis propria can be distinguished with OCT [31-33]. OCT can also differentiate bladder cancer from normal bladder mucosa with a sensitivity and specificity ranging from $84-100 \%$ and $78-90 \%$, respectively [32,34-36]. Two studies have shown that OCT can determine the clinical stage of bladder cancer in real-time. Goh et al., reported $90 \%$ sensitivity and $89 \%$ specificity using OCT to detect superficial bladder cancer, and $100 \%$ sensitivity for detecting muscle invasive disease [35]. Goh et al., demonstrated that OCT could discriminate $\mathrm{Ta}, \mathrm{T} 1$, and $\mathrm{T} 2$ tumors with a sensitivity of $90 \%$, $75 \%$ and $100 \%$, respectively and a specificity of $89 \%, 97 \%$ and $90 \%$, respectively. Zagaynova et al., found that OCT could discriminate between muscle invasive and superficial bladder tumors with $100 \%$ sensitivity and $77 \%$ specificity at the time of TURBT. Although the studies appear promising, some limitations do exist. Inflammation or scarring of the mucosa may lead to false-positives $[35,36]$. The size of the probe limits the field of view making the technique unsuitable for bladder mapping. In addition, large tumors with extensive broadened urothelium imaging depth will be impaired, thus compromising the ability to stage the tumor. In summary, OCT is a noninvasive imaging technique that can provide real-time tissue staging information. More clinical trials are needed before implementing this technology into everyday clinical practice.

\section{Discussion}

The three cystoscopic advancements describe above have advantages and disadvantages. The goal of all these techniques is to improve the detection of superficial bladder cancer. OCT differs dramatically because of its ability to give real-time information on pathologic stage. The clinical impact of improved detection cannot be fully understood until long term studies are done to show the overall effect on morbidity and mortality. However, improved detection should clearly improve outcomes.

One of the most challenging clinical scenarios is a patient with a positive urine cytology report and negative WLC: "invisible tumor." Schwalb et al., reported up to $15 \%$ of patients with positive urine cytology might have no detectable tumor after WLC [38]. Approximately, $75 \%$ of these patients will have a visible tumor on follow up WLC [38]. FC has been shown to improve detection on the initial exam, and this may be true for NBI as well. Random biopsies are still recommended by the National Comprehensive Cancer Network [39], however targeted biopsies using FC or NBI seems to be more rational. Carcinoma in situ (CIS) lesions are particularly problematic. Schmidbauer et al., reported $67 \%$ increased detection of CIS lesions with FC when compared to WLC [9]. Ray et al., showed that additional pathology was detected by FC in $32 \%$ of patients with confirmed positive urinary cytology and negative WLC [3]. Indisputably earlier detection of CIS lesions will result in a more complete transurethral resection with lower early recurrence rates and potential improve overall survival. No official recommendations have been made by the American Urology Association; however, the European Association of Urology has recommended it for the diagnosis of carcinoma in situ of the bladder when available [46]. The body of literature supporting the use of FC is larger; however both $\mathrm{FC}$ and NBI appear to be promising techniques for the treatment of patients with unconfirmed positive urine cytology.

Another difficulty in the management of bladder cancer is the high recurrence rate. Recurrent tumors have been found in $30-44 \%$ of patients at 2-8 weeks following initial bladder resection [37]. Because of this fact, periodic urinary cytology and cystoscopic examinations are required. The imperfect sensitivity of traditional WLC may explain the high rate of cancer recurrence. The most likely explanation for the recurrence is that non-visible cancer is present at the time of resection. Enhanced visibility of the tumor can decrease recurrence rates by improving the transurethral resection. FC has already been shown to statistically lower residual tumor rates [19]. Fluorescent TURBT also significantly reduces the incidence of tumor recurrence [48-51]. The NBI and OCT techniques presented in this review could lead to a more complete resection however this question remains to be answered. The high recurrence rates of bladder cancer make it the highest lifetime treatment costs per patient of all cancers [42]. The American Cancer Society estimates the cost of nonmuscle invasive bladder cancer at $\$ 31.5$ million per year in the United States [43]. One of the obstacles facing complete 
Hale et al. Medical Instrumentation 2013,

implementation of these new cystoscopic approaches is the believed economic burden. Specialized cystoscopes, light source, and light cables cost an additional $\$ 30,000$ 40,000 . Sievert et al., performed an economic comparison of conventional TURBT versus FC assisted TURBT which proved to be economically friendly due to the decreased rate of recurrence [44]. This occurred despite the initial increase in cost for added equipment and intravesical infusion. Each HAL dose costs approximately $\$ 600$. A similar study from Sweden estimated over $\$ 600,000$ could be saved by simply performing TURBT under FC on high risk patients in the first year [45]. NBI and OCT could prove to be more cost effective because no intravesical instillation is required. However, the cost analysis of NBI and OCT has yet to be performed.

The review of literature supports the utilization of each of these modalities in order to optimize bladder cancer detection and treatment. More research is needed before $\mathrm{FC}, \mathrm{NBI}$ or OCT can be completely implemented into common practice. Longterm randomized trials are still needed to determine improved recurrence rates, morbidity and mortality. At this conjuncture, it is difficult to tell if one of these technologies may emerge as the new standard of care and replace WLC, or if the standard of care will become a combination of these optical techniques. One thing is certain that these technological advancements are revolutionizing the detection of superficial bladder tumors.

\section{Competing interests}

The authors declare that they have no competing interests.

\section{Authors' contributions}

Nathan Hale: Primary Author.

Samuel Deem: Secondary Author and Chief Editor.

\section{Publication history}

Editor: Timothy C. Zhu, University of Pennsylvania, USA.

EIC: Robert A. Lodder, University of Kentucky, USA.

Received: 12-Mar-2013 Revised: 18-Jun-2013

Accepted: 12-July-2013 Published: 02-Aug-2013

\section{References}

1. Jemal A, Bray F, Center MM, Ferlay J, Ward E and Forman D. Global cancer statistics. CA Cancer J Clin. 2011; 61:69-90. | Article | PubMed

2. Ries LA, Eisner MP, Kosary CL, Hankey BF, Miller BA, Clegg L et al. SEER Cancer Statistics Review, 1975-2000. Bethesda: National Cancer Institute, 2003. I Pdf

3. Sylvester RJ, van der Meijden AP, Oosterlinck W, Witjes JA, Bouffioux C, Denis L, Newling DW and Kurth K. Predicting recurrence and progression in individual patients with stage Ta T1 bladder cancer using EORTC risk tables: a combined analysis of $\mathbf{2 5 9 6}$ patients from seven EORTC trials. Eur Urol. 2006; 49:466-5; discussion 475-7. | Article | PubMed

4. Madeb R, Golijanin D, Knopf J and Messing EM. Current state of screening for bladder cancer. Expert Rev Anticancer Ther. 2007; 7:981-7. | Article | PubMed

5. Jocham D, Stepp $H$ and Waidelich $R$. Photodynamic diagnosis in urology: State-of-the-Art. Eur Urol. 2002; 41:523-31. | Article

6. Jakse G, Algaba F, Malmstrom PU and Oosterlinck W. A second-look TUR in T1 transitional cell carcinoma: why? Eur Urol. 2004; 45:539-46. Article I PubMed

7. Gorin M, Ayyathurai R and Soloway M. Transurethral management of urothelial carcinoma of the bladder. AUA Update Series 2011; 30:210219. | Pdf

8. Zaak D, Hungerhuber E, Schneede P, Stepp H, Frimberger D, Corvin $\mathrm{S}$, Schmeller N, Kriegmair M, Hofstetter A and Knuechel R. Role of 5-aminolevulinic acid in the detection of urothelial premalignant lesions. Cancer. 2002; 95:1234-8. | Article | PubMed

9. Schmidbauer J, Witjes F, Schmeller N, Donat R, Susani M and Marberger M. Improved detection of urothelial carcinoma in situ with hexaminolevulinate fluorescence cystoscopy. J Urol. 2004; 171:135-8. | Article I PubMed

10. Loidl W, Schmidbauer J, Susani M and Marberger M. Flexible cystoscopy assisted by hexaminolevulinate induced fluorescence: a new approach for bladder cancer detection and surveillance? Eur Urol. 2005; 47:3236. | Article | PubMed

11. Witjes JA, Moonen PM and van der Heijden AG. Comparison of hexaminolevulinate based flexible and rigid fluorescence cystoscopy with rigid white light cystoscopy in bladder cancer: results of a prospective Phase II study. Eur Urol. 2005; 47:319-22. | Article | PubMed

12. Jocham D, Stepp $H$ and Waidelich R. Photodynamic diagnosis in urology: state-of-the-art. Eur Urol. 2008; 53:1138-48. | Article | PubMed

13. Zaak D, Kriegmair M, Stepp H, Baumgartner R, Oberneder R, Schneede $P$, Corvin S, Frimberger D, Knuchel R and Hofstetter A. Endoscopic detection of transitional cell carcinoma with 5-aminolevulinic acid: results of 1012 fluorescence endoscopies. Urology. 2001; 57:690-4. | Article | PubMed

14. Hungerhuber E, Stepp H, Kriegmair M, Stief C, Hofstetter A, Hartmann A, Knuechel R, Karl A, Tritschler S and Zaak D. Seven years' experience with 5-aminolevulinic acid in detection of transitional cell carcinoma of the bladder. Urology. 2007; 69:260-4. | Article | PubMed

15. Grossman HB, Gomella L, Fradet Y, Morales A, Presti J, Ritenour C, Nseyo $U$ and Droller MJ. A phase III, multicenter comparison of hexaminolevulinate fluorescence cystoscopy and white light cystoscopy for the detection of superficial papillary lesions in patients with bladder cancer. J Urol. 2007; 178:62-7. | Article I PubMed

16. Fradet Y, Grossman HB, Gomella L, Lerner S, Cookson M, Albala D and Droller MJ. A comparison of hexaminolevulinate fluorescence cystoscopy and white light cystoscopy for the detection of carcinoma in situ in patients with bladder cancer: a phase III, multicenter study. $J$ Urol. 2007; 178:68-73. | Article | PubMed

17. Schmidbauer J, Witjes F, Schmeller N, Donat R, Susani M and Marberger M. Improved detection of urothelial carcinoma in situ with hexaminolevulinate fluorescence cystoscopy. J Urol. 2004; 171:135-8. | Article | PubMed

18. Jichlinski P, Guillou L, Karlsen SJ, Malmstrom PU, Jocham D, Brennhovd B, Johansson E, Gartner T, Lange N, van den Bergh $\mathrm{H}$ and Leisinger HJ. Hexyl aminolevulinate fluorescence cystoscopy: new diagnostic tool for photodiagnosis of superficial bladder cancer--a multicenter study. $J$ Urol. 2003; 170:226-9. | Article | PubMed

19. Kausch I, Sommerauer M, Montorsi F, Stenzl A, Jacqmin D, Jichlinski P, Jocham D, Ziegler A and Vonthein R. Photodynamic diagnosis in nonmuscle-invasive bladder cancer: a systematic review and cumulative analysis of prospective studies. Eur Urol. 2010; 57:595-606. | Article | PubMed

20. Kuznetsov K, Lambert R and Rey JF. Narrow-band imaging: potential and limitations. Endoscopy. 2006; 38:76-81. I Article I PubMed

21. Song LM, Adler DG, Conway JD, Diehl DL, Farraye FA, Kantsevoy SV, Kwon R, Mamula P, Rodriguez B, Shah RJ and Tierney WM. Narrow band imaging and multiband imaging. Gastrointest Endosc. 2008; 67:581-9. | Article I PubMed

22. Cauberg EC, Kloen S, Visser M, de la Rosette JJ, Babjuk M, Soukup V, Pesl M, Duskova J and de Reijke TM. Narrow band imaging cystoscopy improves the detection of non-muscle-invasive bladder cancer. Urology. 2010; 76:658-63. | Article | PubMed

23. Herr HW and Donat SM. A comparison of white-light cystoscopy and narrow-band imaging cystoscopy to detect bladder tumour 
Hale et al. Medical Instrumentation 2013,

recurrences. BJU Int. 2008; 102:1111-4. | Article | PubMed

24. Herr HW. Narrow-band imaging cystoscopy to evaluate the response to bacille Calmette-Guerin therapy: preliminary results. BJU Int. 2010; 105:314-6. | Article | PubMed

25. Naselli A, Introini C, Bertolotto F, Spina B and Puppo P. Narrow band imaging for detecting residual/recurrent cancerous tissue during second transurethral resection of newly diagnosed non-muscle-invasive highgrade bladder cancer. BJU Int. 2010; 105:208-11. I Article I PubMed

26. Bryan RT, Billingham $L$ and Wallace DM. Narrow-band imaging flexible cystoscopy in the detection of recurrent urothelial cancer of the bladder. BJU Int. 2008; 101:702-5. | Article | PubMed

27. Tatsugami K, Kuroiwa K, Kamoto T, Nishiyama H, Watanabe J, Ishikawa S, Shinohara N, Sazawa A, Fukushima S and Naito S. Evaluation of narrowband imaging as a complementary method for the detection of bladder cancer. J Endourol. 2010; 24:1807-11. | Article I PubMed

28. Herr HW and Donat SM. Reduced bladder tumour recurrence rate associated with narrow-band imaging surveillance cystoscopy. BJU Int. 2011; 107:396-8. | Article | PubMed

29. de la Rosette J and Gravas S. A multi-center, randomized international study to compare the impact of narrow band imaging versus white light cystoscopy in the recurrence of bladder cancer. J Endourol. 2010; 24:660-1. | Article | PubMed

30. Zysk AM, Nguyen FT, Oldenburg AL, Marks DL and Boppart SA. Optical coherence tomography: a review of clinical development from bench to bedside. J Biomed Opt. 2007; 12:051403. I Article I PubMed

31. Jesser CA, Boppart SA, Pitris C, Stamper DL, Nielsen GP, Brezinski ME and Fujimoto JG. High resolution imaging of transitional cell carcinoma with optical coherence tomography: feasibility for the evaluation of bladder pathology. Br J Radiol. 1999; 72:1170-6. I Article I PubMed

32. Hermes B, Spoler F, Naami A, Bornemann J, Forst M, Grosse J, Jakse G and Knuchel R. Visualization of the basement membrane zone of the bladder by optical coherence tomography: feasibility of noninvasive evaluation of tumor invasion. Urology. 2008; 72:677-81. | Article | PubMed

33. Tearney GJ, Brezinski ME, Southern JF, Bouma BE, Boppart SA and Fujimoto JG. Optical biopsy in human urologic tissue using optical coherence tomography. Med Phys. 2001; 28:2432-40. | Article | PubMed

34. Manyak MJ, Gladkova ND, Makari JH, Schwartz AM, Zagaynova EV, Zolfaghari L, Zara JM, Iksanov R and Feldchtein FI. Evaluation of superficial bladder transitional-cell carcinoma by optical coherence tomography. J Endourol. 2005; 19:570-4. | Article | PubMed

35. Goh AC, Tresser NJ, Shen SS and Lerner SP. Optical coherence tomography as an adjunct to white light cystoscopy for intravesical realtime imaging and staging of bladder cancer. Urology. 2008; 72:133-7. | Article I PubMed

36. Ren H, Waltzer WC, Bhalla R, Liu J, Yuan Z, Lee CS, Darras F, Schulsinger D, Adler HL, Kim J, Mishail A and Pan Y. Diagnosis of bladder cancer with microelectromechanical systems-based cystoscopic optical coherence tomography. Urology. 2009; 74:1351-7. | Article | PubMed Abstract | PubMed Full Text

37. Herr HW and Donat SM. Quality control in transurethral resection of bladder tumours. BJU Int. 2008; 102:1242-6. | Article | PubMed

38. Schwalb DM, Herr HW and Fair WR. The management of clinically unconfirmed positive urinary cytology. J Urol. 1993; 150:1751-6. | PubMed

39. NCCN Guideline 2.2011 Bladder Cancer. I Pdf

40. Ray ER, Chatterton K, Khan MS, Thomas K, Chandra A and O'Brien TS. Hexylaminolaevulinate 'blue light' fluorescence cystoscopy in the investigation of clinically unconfirmed positive urine cytology. BJU Int 2009; 103:1363-7. | Article | PubMed

41. Ray ER, Chatterton K, Khan MS, Chandra A, Thomas K, Dasgupta P and O'Brien TS. Hexylaminolaevulinate fluorescence cystoscopy in patients previously treated with intravesical bacille Calmette-Guerin. BJU Int. 2010; 105:789-94. | Article | PubMed

42. Miller BA, Kolonel LN, BernStein L et al. Racial/ethnic patterns of cancer in the United States. National Cancer Institute. 1996. I Pdf
43. Han M and Schoenberg MP. The use of molecular diagnostics in bladder cancer. Urol Oncol. 2000; 5:87-92. | Article | PubMed

44. Sievert KD, Amend B, Nagele U, Schilling D, Bedke J, Horstmann M, Hennenlotter J, Kruck S and Stenzl A. Economic aspects of bladder cancer: what are the benefits and costs? World J Urol. 2009; 27:295-300 | Article | PubMed Abstract | PubMed Full Text

45. Malmstrom PU and Hedelin $\mathrm{H}$. Potential cost savings through the use of fluorescence cystoscopy superficial bladder cancer: development of an economic model. Urology. 2006; 68:40-41. | Article

46. Babjuk M, Oosterlinck W, Sylvester R, Kaasinen E, Bohle A, Palou-Redorta $J$ and Roupret M. EAU guidelines on non-muscle-invasive urothelial carcinoma of the bladder, the 2011 update. Eur Urol. 2011; 59:9971008. | Article | PubMed

47. Schumacher MC, Holmang S, Davidsson T, Friedrich B, Pedersen J and Wiklund NP. Transurethral resection of non-muscle-invasive bladder transitional cell cancers with or without 5-aminolevulinic Acid under visible and fluorescent light: results of a prospective, randomised, multicentre study. Eur Urol. 2010; 57:293-9. | Article I PubMed

48. Denzinger S, Burger M, Walter B, Knuechel R, Roessler W, Wieland $\mathrm{WF}$ and Filbeck T. Clinically relevant reduction in risk of recurrence of superficial bladder cancer using 5-aminolevulinic acid-induced fluorescence diagnosis: 8-year results of prospective randomized study. Urology. 2007; 69:675-9. I Article I PubMed

49. Daniltchenko DI, Riedl CR, Sachs MD, Koenig F, Daha KL, Pflueger H, Loening SA and Schnorr D. Long-term benefit of 5-aminolevulinic acid fluorescence assisted transurethral resection of superficial bladder cancer: 5-year results of a prospective randomized study. J Urol. 2005; 174:2129-33. | Article | PubMed

50. Stenzl A, Burger M, Fradet Y, Mynderse LA, Soloway MS, Witjes JA, Kriegmair M, Karl A, Shen $Y$ and Grossman HB. Hexaminolevulinate guided fluorescence cystoscopy reduces recurrence in patients with nonmuscle invasive bladder cancer. J Urol. 2010; 184:1907-13. | Article I PubMed

51. Babjuk M, Soukup V, Petrik R, Jirsa M and Dvoracek J. 5-aminolaevulinic acid-induced fluorescence cystoscopy during transurethral resection reduces the risk of recurrence in stage $\mathrm{Ta} / \mathrm{T} 1$ bladder cancer. $B J U$ Int 2005; 96:798-802. | Article | PubMed

Citation:

Hale NE and Deem S. Advances in cystoscopic surveillance of superficial bladder cancer: detection of the invisible tumor. Med Instrum. 2013; 1:6. http://dx.doi.org/10.7243/2052-6962-1-6 